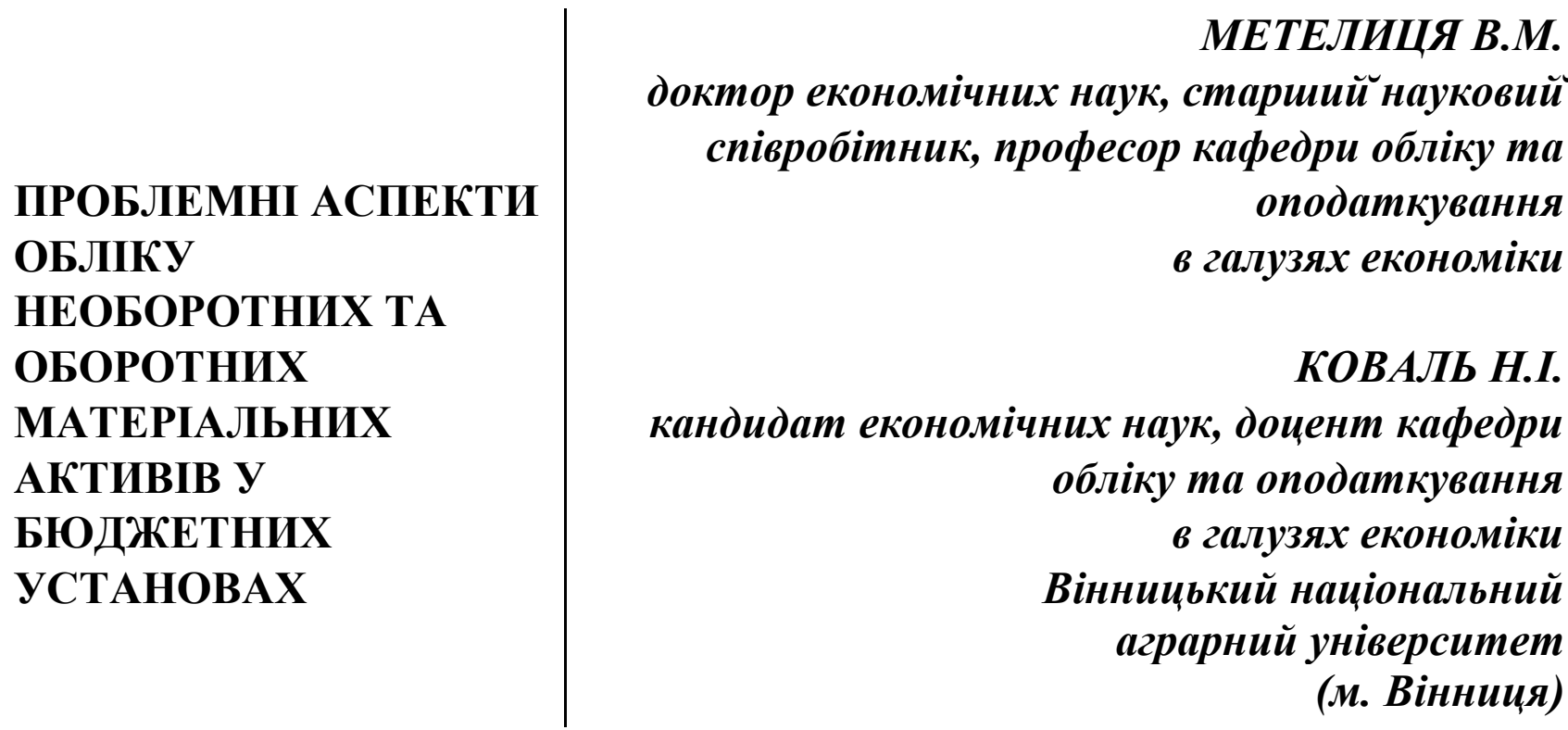

У пропонованій статті досліджено сучасний стан облікового супроводження оборотних та необоротних матеріальних активів у бюджетних установах. Аналіз надходження необоротних матеріальних активів дозволив акиентувати увагу на проблематиці застування вартісного критерію при віднесенні активу до основних засобів або інших необоротних матеріальних активів. Застосування вартісного критерію у наш час $\epsilon$ недосконалим методом групування необоротних матеріальних активів за класифікаційними групами, оскільки визначення активу в деяких випадках залежить від системи оподаткування постачальника. Визначення даної проблематики дозволило запропонувати иляхи ї̈ розв'язання, де перша пропозичія полягає у відмові від відокремлення податку на додану вартість від иіни активу, а друга - у визначенні активу за групами, спираючись на його властивості без прив'язки до його вартості. Кожна із запропонованих пропозииій має свої переваги, але, враховуючи інфлячійні чинники та нестабільність економічних прочесів, групування необоротних матеріальних активів потрібно здійснювати шляхом аналізу характеристик, властивостей активу без прив'язки до його вартості.

Друга частина иієї статті присвячена дослідженню методу вибуття запасів, які надійшли внаслідок внутрішньовідомчого переміщення в межах уповноваженого органу. Встановлено, щуо иеей вид запасів має свою специфіку, пов 'язану з його надходженням до сфери управління та використання в діяльності бюджетних установ. Враховуючи зазначені чинники, в статті запропоновано законодавчо затвердити вибуття цьього виду запасів тільки иляхом використання методу ідентифікованої собівартості відповідної одиниці запасу, щуо дозволить забезпечити достовірність відображення фінансової та бюджетної звітності не тільки в окремій бюджетній установі, але й за уповноваженим органом загалом.

Запропоновані удосконалення обліку необоротних та оборотних матеріальних активів дозволять покращити фінансову та бюджетну звітність бюджетних установ, привести бюджетний облік до міжнародних та європейських стандартів, а також покращить якість планування в бюджетних установах. 
Ключові слова: необоротні матеріальні активи, оборотні матеріальні активи, основні засоби, запаси, ідентифікована собівартість, вартісний критерій.

Рис.: 1. Табл.: 1. Літ.: 9.

\title{
PROBLEMATIC ASPECTS OF ACCOUNTING FOR NON-CURRENT AND CURRENT TANGIBLE ASSETS IN BUDGETARY INSTITUTIONS
}

\author{
METELYTSYA Volodymyr, \\ Doctor of Economics, Senior Researcher, \\ Professor of the Accounting and Taxation in \\ Economics Department
}

\author{
KOVAL Natalia, \\ Ph.D, lecturer Departments of account and \\ taxation are in industries of economy \\ Vinnytsia National Agrarian University \\ (Vinnytsia)
}

This article examines the current state of accounting support for current and non-current
tangible assets in budgetary institutions. The analysis of the receipt of non-current tangible assets allowed us to focus on the issue of stagnation of the value criterion when assigning the asset to fixed assets or other non-current tangible assets. The application of the value criterion is currently an imperfect method of grouping non-current tangible assets by classification groups, because the definition of an asset in some cases depends on the supplier's taxation system. The definition of this problem allowed to suggest ways to solve it, where the first proposal is to refuse to separate value added tax from the price of the asset, and the second is to determine the asset by groups based on its properties without reference to its value. Each of the proposed proposals has its advantages, but given the inflationary factors and the instability of economic processes, the grouping of non-current tangible assets should be done by analyzing the characteristics, properties of the asset without reference to its value.

The second part of this article is devoted to the study of the method of disposal of stocks received as a result of intra-departmental movement within the authorized body. It is established that this type of stocks has its own specifics associated with its receipt in the field of management and use in the activities of budgetary institutions. Taking into account these factors, the article proposes to legislate the disposal of this type of stock only by using the method of identified cost of the relevant unit of stock. This will ensure the reliability of the financial and budgetary reporting not only in a particular budgetary institution, but also in general by the authorized body.

The proposed improvements in the accounting of non-current and current tangible assets will improve the financial and budgetary reporting of budgetary institutions, bring budgetary accounting to international and European standards, as well as improve the quality of planning in budgetary institutions.

Key words: non-current tangible assets, current tangible assets, fixed assets, inventories, identified cost, cost criterion.

Fig.: 1. Tabl.: 1. Lit.: 9. 


\title{
ПРОБЛЕМНЫЕ АСПЕКТЫ УЧЕТА НЕОБОРОТНЫХ И ОБОРОТНЫХ МАТЕРИАЛЬНЫХ АКТИВОВ В БЮДЖЕТНЫХ УЧРЕЖДЕНИЯХ
}

\author{
МЕТЕЛИЦА В.М. \\ доктор экономических наук, старший научный \\ сотрудник, профессор кафедры учета и \\ налогообложения в отраслях экономики \\ КОВАЛЬ Н. И. \\ кандидат экономических наук, доцент кафедры \\ кафедры учета и налогообложения \\ в отраслях экономики \\ Винницкий национальный аграрный университет
} (2. Винница)

В данной статье исследовано современное состояние учетного сопровождения оборотных и необоротных материальных активов в бюджетных учреждениях. Анализ поступления необоротных материальных активов позволил акцентировать внимание на проблематике применения стоимостного критерия при отнесении актива к основным средствам или к другим необоротным материальным активам. Применение стоимостного критерия в настоящее время является несовершенным методом группировки необоротных материальных активов по классификационным группам, ведь определение актива в некоторых случаях зависит от системы налогообложения поставщика. Определение данной проблематики разрешило предложить пути ее решения, где первое предложение заключается в отказе от отделения налога на добавленную стоимость от иены актива, а вторая заключается в определении актива по группам опираясь на его свойства без привязки $\kappa$ его стоимости. Каждая из предложенных предложений имеет свои преимущества, но учитывая инфляционные факторы и нестабильность экономических процессов группировки необоротных материальных активов следует осуществлять путем анализа характеристик, свойств актива без привязки кего стоимости.

Вторая часть этой статьи посвящена исследованию метода списания запасов, поступивших в результате внутриведомственного перемещения в пределах уполномоченного органа. Установлено, что данный вид запасов имеет свою специфику, связанную с его поступлением в сфере управления и использования в деятельности бюджетных учреждений. Учитывая данные факторы в статье предложено законодательно утвердить списания данного вида запасов только путем использования метода идентифицированной себестоимости соответствующей единиць запаса. Это позволит обеспечить достоверность отражения финансовой и бюджетной отчетности не только в отдельном бюджетном учреждении, но и в целом по уполномоченным органом.

Предложенные усовершенствования учета необоротных и оборотных материальных активов позволят улучшить финансовую и бюджетную отчетность бюджетных учреждений, привести бюджетный учет кмеждународным и европейским стандартам, $а$ также улучшить качество планирования в бюджетных учреждениях. 
Ключевые слова: необоротные материальные активы, оборотные материальные активы, основные средства, запасы, идентифицирована себестоимость, стоимостный критерий.

Рис.: 1. Табл.: 1. Лит.: 9.

Постановка проблеми. Сучасний етап розвитку нашої країни характеризується прагненням суспільства та політичної еліти до європейської інтеграції України не тільки в політичному, але й в економічному напрямку. Вплив інтеграційних процесів змусив уряд нашої країни кардинально змінити погляди на бухгалтерський облік у бюджетних установах, що, насамперед, вплинуло на облікове відображення необоротних та оборотних матеріальних активів.

Будь-яка новизна потребує часу для практичної реалізації, тільки після m чого можна буде стверджувати про іï ефективність та доцільність. Наявність 之. невизначеності в облікових процесах бюджетних установ щодо обліку необоротних та оборотних матеріальних активів призвело до необхідності аналізу особливостей їхнього функціонування та надання рекомендацій щодо усунення суперечностей задля приведення норм бюджетного обліку до міжнародного рівня.

Аналіз останніх досліджень і публікацій. Значущість та важливість облікового процесу в бюджетних установах висвітлюється в працях вітчизняних вчених. Особливий внесок у дослідження питання удосконалення обліку бюджетних установ зробили: П. Й. Атамас, Ф. Ф. Бутинець [9], Р. Т. Джога, Т. М. Писаренко [5], С. В. Свірко [8], Т. В. Черкашина, О. О. Чечуліна та інші. Але, незважаючи на їхні дослідження, досі залишаються питання, які потребують додаткового вивчення.

Формування цілей статті. Метою роботи $\epsilon$ аналіз сучасного стану облікового забезпечення та супроводження необоротних та оборотних матеріальних активів у бюджетних установах, ідентифікація проблем та пропозиції щодо їх вирішення.

Виклад основного матеріалу дослідження. Облік необоротних та оборотних матеріальних активів в бюджетних установах регламентується національними положеннями стандартами бухгалтерського обліку в державному секторі. Необоротні та оборотні матеріальні активи за своєю суттю відносяться до активів, які утримуються для використання їх у діяльності бюджетної установи задля задоволення потреб суб'єкта державного сектору. Головна відмінність їх полягає у строках експлуатації та вартісних показниках. Так, переважний строк експлуатації оборотних матеріальних активів не перевищує одного року. Натомість необоротні матеріальні активи використовуються в бюджетних установах значно більший термін. Незважаючи на наявність 
спільних характеристик, підходи до їх облікового супроводження в бюджетних установах суттєво відрізняються, тому і наявна проблематика проявляється порізному.

На даний час необоротні матеріальні активи структурно можливо поділити на дві складові, такі як основні засоби та інші необоротні матеріальні активи. У положеннях національних стандартів бухгалтерського обліку в державному секторі 121 «Основні засоби» основні засоби та інші необоротні матеріальні активи об'єднують між собою в один термін - «основні засоби» і дають йому таке трактування: матеріальні активи, які утримуються для використання їх у виробництві/діяльності або при постачанні товарів, виконанні робіт і наданні послуг для досягнення поставленої мети та/або задоволення потреб суб'єкта державного сектору або здавання в оренду іншим особам і використовуються, за очікуванням, більше одного року [2].

Краще усвідомлення суті та призначення необоротних матеріальних активів варто здійснити шляхом розподілу їх за класифікаційними групами (рис. $1)$.

\begin{tabular}{|c|c|}
\hline \multicolumn{2}{|c|}{ Класифікація необоротних матеріальних активів } \\
\hline Основні засоби & Інші необоротні матеріальні активи \\
\hline $\begin{array}{l}\text { - Земельні ділянки; } \\
\text { - Капітальні витрати на поліпшення } \\
\text { земель. } \\
\text { - Будинки, споруди та передавальні } \\
\text { пристрої. } \\
\text { - Машини та обладнання. } \\
\text { - Транспортні засоби. } \\
\text { - Інструменти, прилади, інвентар. } \\
\text { - Тварини, багаторічні насадження та } \\
\text { плодоносні рослини. } \\
\text { - Інші основні засоби. }\end{array}$ & $\begin{array}{l}\text { - Музейні фонди. } \\
\text { - Бібліотечні фонди. } \\
\text { - Малоцінні необоротні матеріальні } \\
\text { активи. } \\
\text { - Білизна, постільні речі, одяг та взуття. } \\
\text { - Природні ресурси. } \\
\text { - Інвентарна тара. } \\
\text { - Необоротні матеріальні активи } \\
\text { спеціального призначення. } \\
\text { - Інші необоротні матеріальні активи. }\end{array}$ \\
\hline
\end{tabular}

Рис. 1. Класифікація необоротних матеріальних активів шляхом поділу їх за групами

Джерело: сформовано автором на підставі [2]

На сучасному етапі одним із суттєвих критеріїв, які впливають на визначення та віднесення активу до основних засобів або інших необоротних матеріальних активів, є його ціна. Відповідно до Методичних рекомендацій 3 обліку основних засобів, до малоцінних необоротних матеріальних активів, які входять до складу інших необоротних матеріальних активів, включаються 
активи, вартість яких складає до 6000 гривень включно за одиницю (комплект) без податку на додану вартість [3].

Таким чином бухгалтери бюджетних установ у прийнятті рішення щодо віднесення активу до складу основного засобу або іншого необоротного матеріального активу сковані вартісним критерієм цього активу, що, на нашу думку, є недосконалим підходом. Тим паче, на визначення вартісної межі впливає наявність або відсутність податку на додану вартість. Тобто у випадку купівлі активу, наприклад, периферійного обладнання вартістю 7000,00 гривень у фізичної особи підприємця (не платника податку на додану вартість) даний актив має належати до складу основних засобів. Натомість купівля аналогічного активу з аналогічною вартістю вже у юридичної особи, яка є платником податку на додану вартість, спричиняє ситуацію, коли даний актив має належати вже до складу малоцінних необоротних матеріальних активів. Наявність неоднозначності в підходах при віднесенні активу до основних засобів або інших необоротних матеріальних активів спричиняє до відсутності уніфікованого підходу, що негативно впливає на побудову системи бюджетного обліку.

Наявність вищезазначеної неоднозначності при визначенні необоротних матеріальних активів негативно впливає на процес планування в бюджетних установах. Планування в кожній бюджетній установі починається 3 затвердження кошторису, відповідно до порядку та вимог, передбачених постановою Кабінету міністрів України №228 від 28 лютого 2002 року [4].

Установам можуть виділятися бюджетні кошти тільки за наявності затверджених кошторисів. Одержувач використовує бюджетні кошти на підставі плану використання бюджетних коштів, що містить розподіл бюджетних асигнувань, затверджених у кошторисі відповідного розпорядника бюджетних коштів [5].

Кошторис - основний плановий фінансовий документ бюджетної установи, яким на бюджетний період встановлюються повноваження щодо отримання надходжень і розподіл бюджетних асигнувань на взяття бюджетних зобов’язань та здійснення платежів для виконання бюджетною установою своїх функцій та досягнення результатів, визначених відповідно до бюджетних призначень [6].

Сьогодні діяльність держави щодо формування, розгляду, затвердження та виконання бюджету - бюджетний процес, який регламентується бюджетним регламентом - документом, в якому визначаються порядок і терміни складання, розгляду і затвердження бюджету, а також організація його виконання [1].

Кошторис має такі складові частини:

- загальний фонд, який містить обсяг надходжень із загального фонду бюджету та розподіл видатків за повною економічною класифікацією видатків бюджету на виконання бюджетною установою (далі - установа) основних 
функцій або розподіл надання кредитів 3 бюджету за класифікацією кредитування бюджету;

- спеціальний фонд, який містить обсяг надходжень із спеціального фонду бюджету на конкретну мету та їх розподіл за повною економічною класифікацією видатків бюджету на здійснення відповідних видатків згідно із законодавством, а також на реалізацію пріоритетних заходів, пов'язаних 3 виконанням установою основних функцій, або розподіл надання кредитів 3 бюджету згідно із законодавством за класифікацією кредитування бюджету [4].

Використання вартісного методу при визначенні активу при здійсненні планування несе певні загрози. У випадку передбачення в кошторисі бюджетної установи придбання активу та віднесення його до основного засобу неможливо врахувати, чи буде до вартості цього активу входити податок на додану вартість. Відтак, неможливо достовірно здійснити планування виконання кошторису бюджетною установою, адже невідомо, чи відносити такі заходи до поточних або капітальних видатків.

Наявність вартісного критерію при віднесенні активу до складу основних засобів або інших необоротних матеріальних активів призводить до труднощів не тільки при відображенні цього активу в обліку, але й при здійсненні планування доходів і видатків бюджетної установи. Вирішення цієї проблематики, на наш погляд, можливо здійснити двома шляхами. Перший шлях передбачає включати у вартісний критерій податок на додану вартість, тим самим не обмежувати віднесення активу залежно від форми оподаткування постачальника товарно-матеріальних цінностей. Другий шлях (який, на нашу думку, є найраціональнішим та найдоцільнішим) - взагалі відмовитись від вартісного критерію, що дозволить розпорядникам коштів нижчого рівня самостійно визначати належність активу залежно від його властивостей i характеристик. Впровадження однієї з двох пропозицій дозволить уникнути загроз при віднесенні активу при постановці його на облік, а також покращити організацію планування доходів і витрат у бюджетних установах.

Існують певні проблемні питання і у випадку облікового супроводження надходження та вибуття оборотних матеріальних активів у бюджетних установах. Оборотні матеріальні активи переважно складаються з запасів. Запаси - це активи, які:

- утримуються для подальшого продажу, безоплатного розподілу передачі за умов звичайної господарської діяльності;

- перебувають у процесі звичайної діяльності суб'єкта державного сектору для подальшого споживання;

- перебувають у формі сировини чи допоміжних матеріалів для використання у виробництві продукції, при виконанні робіт, наданні послуг або 
для досягнення поставленої мети та/або задоволення потреб суб'єкта державного сектору [7].

На сьогодні досить неоднозначним є питання вибуття запасів, отриманих безоплатно в межах уповноваженого органу. Методи оцінки вибуття запасів в державному секторі чітко регламентовані й визначені (табл. 1).

Для забезпечення раціонального використання ресурсів, дотримання фінансово-бюджетної дисципліни важливу роль відіграє реалізація таких функцій управління як облік і контроль. Удосконалення організації обліку запасів, забезпечення його контрольних функцій за господарською і фінансовою діяльністю бюджетних організацій є основою дотримання обліку в бюджетних установах. Висока якість облікової інформації створює умови ефективної реалізації всіх функцій управління [8, с.152].

Табличя 1

Методи вибуття запасів у бюджетних установах та їх характеристика

\begin{tabular}{|c|c|}
\hline Методи вибуття запасів & Характеристика \\
\hline $\begin{array}{l}\text { Ідентифікованої } \\
\text { собівартості } \\
\text { відповідної одиниці } \\
\text { запасів }\end{array}$ & $\begin{array}{l}\text { запаси, які відпускаються, та послуги, що виконуються для спеціальних } \\
\text { замовлень і проектів, а також запаси, які не замінюють один одного }\end{array}$ \\
\hline $\begin{array}{l}\text { Середньозваженої } \\
\text { собівартості }\end{array}$ & $\begin{array}{l}\text { проводиться щодо кожної одиниці запасів діленням сумарної вартості } \\
\text { залишку таких запасів на початок звітного місяця і вартості одержаних у } \\
\text { звітному місяці запасів на сумарну кількість запасів на початок звітного } \\
\text { місяця і одержаних у звітному місяці запасів }\end{array}$ \\
\hline $\begin{array}{l}\text { Собівартості перших за } \\
\text { часом } \quad \text { надходження } \\
\text { запасів (ФІФО) }\end{array}$ & $\begin{array}{l}\text { базується на припущенні, що запаси використовуються у тій } \\
\text { послідовності, у якій вони надходили до суб'єкта державного сектору } \\
\text { (відображені у бухгалтерському обліку), тобто запаси, які першими } \\
\text { відпускаються у виробництво (продаж та інше вибуття), оцінюються за } \\
\text { собівартістю перших за часом надходження запасів }\end{array}$ \\
\hline
\end{tabular}

Джсерело: сформовано автором на основі [7]

Списання використаних запасів, отриманих безоплатно в межах уповноваженого органу, відображається в бухгалтерському обліку як зменшення балансової вартості цих запасів та зобов'язань за розрахунками з їх внутрішнього переміщення (внутрішньовідомчої безоплатної передачі). У бухгалтерському обліку суб'єкта державного сектору, що передав ці запаси, таке списання відображається як збільшення витрат та зменшення дебіторської заборгованості за розрахунками з внутрішнього переміщення (внутрішньовідомчої безоплатної передачі) запасів на підставі акту списання, отриманого від суб'єкта державного сектору, що їх використав [7].

Бутинець Ф.Ф. стверджує, що при виборі методу оцінки вибуття запасів підприємство виходить з інтересів користувачів звітності [9, с. 323].

Зважаючи на зазначені обставини, на нашу думку, законодавцю необхідно передбачити списання запасів у межах уповноваженого органу шляхом 
застосування методу ідентифікованої собівартості відповідно до одиниці запасів. Це дозволить визначити єдиний уніфікований метод для списання запасів, отриманих у межах одного розпорядника коштів, та забезпечить достовірність відображення інформації в фінансовій та бюджетній звітності.

Висновки. Облік в бюджетних установах не втрачає своєї актуальності незалежно від економічних процесів та світових тенденцій. Ефективне та раціональне використання наявного майна та ресурсів, які знаходяться у власності держави, завжди буде запорукою успішних економічних реформ та соціальних звершень. Досягнути цього можливо тільки завдяки удосконаленню наявної системи бюджетного обліку та приведення іiї до світових норм.

Необоротні та оборотні матеріальні активи складають найбільшу частину серед активів у бюджетних установах, тому вивчення проблематики їх облікового забезпечення та надання власних пропозицій з їх усунення завжди будуть ставитись в пріоритеті у вітчизняних та зарубіжних науковців. На сьогодні віднесення необоротних матеріальних активів за класифікаційними групами потребує удосконалення. Відмова від вартісного критерію при визначенні приналежності активу дозволить покращити не тільки облікові процеси, але й забезпечить якісне формування планових показників видатків на наступні роки.

У свою чергу потребує законодавчої регламентації порядок вибуття запасів отриманих у межах уповноваженого органу. Дослідивши природу надходження цих запасів та їх облікове супроводження, ми дійшли висновку, що єдиний метод, який забезпечив би складання достовірної бюджетної та фінансової звітності є метод ідентифікованої собівартості відповідної одиниці запасу. Запровадження запропонованих рекомендацій щодо удосконалення бухгалтерського обліку в бюджетних установах дозволить прискорити процес впровадження міжнародних облікових норм у вітчизняну облікову практику.

\section{Список використаних джерел}

1. Metelytsia V., Koval N., Tomashuk I. Analysis of the budgetary planning organization in Ukraine. The scientific heritage. Hungary. Uhorshchyna. 2020. №46. P. $100-110$.

2. Про затвердження національних положень (стандартів) бухгалтерського обліку в державному секторі 121 "Основні засоби": Наказ М-ва фінансів України від 12 жовт. 2010 р. № 1202. URL: https://zakon.rada.gov.ua/laws/show/z101710\#n18 (дата звернення 08.05.2020)

3. Про затвердження Методичних рекомендацій з бухгалтерського обліку для суб'єктів державного сектору : Наказ М-ва фінансів України від 23 січ. 2015 p. № 11. URL: https://zakon.rada.gov.ua/rada/show/v0011201-15 (дата звернення 06.06.2020) 
4. Про затвердження Порядку складання, розгляду, затвердження та основних вимог до виконання кошторисів бюджетних установ : Постанова КМ України від 28 лют. 2002 р. № 228. URL: https://zakon.rada.gov.ua/laws/show/2282002-n (дата звернення 15.04.2020)

5. Писаренко Т. М. Особливості організації обліку у бюджетних установах. Економічні науки. Сер. : Облік і фінанси. 2013. Вип. 10(2). С. 193-202. URL: http://nbuv.gov.ua/UJRN/ecnof_2013_10\%282\%29_27 (дата звернення 08.06.2020)

6. Бюджетний кодекс України від 08 лип. 2010 р. № 2456-VI (ред. станом на 01.01.2020 p.). URL: https://zakon.rada.gov.ua/laws/show/2456-17 (дата звернення 08.06.2020)

7. Про затвердження національних положень (стандартів) бухгалтерського обліку в державному секторі 123 "Запаси" : Наказ М-ва фінансів України від 12 жовт. 2010 p. № 1202. URL: https://zakon.rada.gov.ua/laws/show/z1017-10\#n18 (дата звернення 10.06.2020)

8. Свірко С. В. Організація бухгалтерського обліку у бюджетних установах : навч. посібн. Київ : КНЕУ, 2006. 380 с.

9. Бутинець Ф.Ф. Бухгалтерський фінансовий облік: Підручник для студентів спеціальності "Облік і аудит" вищих навчальних закладів. Житомир: ПП "Рута", 2003. 726 с.

\section{References}

1. Metelytsia V., Koval N., Tomashuk I. Analysis of the budgetary planning organization in Ukraine. The scientific heritage. Hungary. Uhorshchyna. 2020. №46. P. 100-110 [in English].

2. Nakaz Ministerstva finansiv Ukrayiny Pro zatverdzhennia natsionalnykh polozhen (standartiv) bukhhalterskoho obliku v derzhavnomu sektori 121 "Osnovni zasoby" vid 12 zhovt. 2010 roku № 1202. [About the statement of national provisions (standards) of accounting in the public sector 121 "Fixed assets". Order of the Ministry of Finance of Ukraine from October 12 2010, № 1202]. Retrieved from: https://zakon.rada.gov.ua/laws/show/z1017-10\#n18 [in Ukranian].

3. Nakaz Ministerstva finansiv Ukrayiny Pro zatverdzhennia Metodychnykh rekomendatsii z bukhhalterskoho obliku dlia subiektiv derzhavnoho sektoru vid 23 sich. 2015 roku № 11. [On approval of Methodical recommendations on accounting for public sector entities. Order of the Ministry of Finance of Ukraine from January 23 2015, № 11]. Retrieved from: https://zakon.rada.gov.ua/rada/show/v0011201-15 [in Ukranian].

4. Postanova kabinetu ministriv Ukrayiny Pro zatverdzhennia Poriadku skladannia, rozghliadu, zatverdzhennia ta osnovnykh vymoh do vykonannia koshtorysiv biudzhetnykh ustanov vid 28 liut. 2002 roku №228. [About the statement 
of the Order of drawing up, consideration, the statement and the basic requirements to performance of estimates of budgetary institutions. Resolution of the Cabinet of Ministers of Ukraine from February 28 2002, № 228]. Retrieved from: https://zakon.rada.gov.ua/laws/show/228-2002-n [in Ukranian].

5. Pysarenko, T. M. (2013) Osoblyvosti orhanizatsii obliku u biudzhetnykh ustanovakh [Features of the organization of accounting in budgetary institutions]. Ekonomichni nauky - Economic sciences. 10(2). 193-202. Retrieved from: http://nbuv.gov.ua/UJRN/ecnof_2013_10\%282\%29_27 [in Ukranian].

6. Byudzhetnyy kodeks Ukrayiny vid 08 lyp. 2010 roku №2456-VI [Budget Code of Ukraine] (2010, July 08). Retrieved from: https://zakon.rada.gov.ua/laws/show/2456-17 [in Ukranian].

7. Nakaz Ministerstva finansiv Ukrayiny Pro zatverdzhennia natsionalnykh polozhen (standartiv) bukhhalterskoho obliku v derzhavnomu sektori 123 "Zapasy" vid 12 zhovt. 2010 roku №1202 [On approval of national regulations (standards) of accounting in the public sector 123 "Inventories" from October 12 2010, № 1202]. Retrieved from: https://zakon.rada.gov.ua/laws/show/z1017-10\#n18 [in Ukranian].

8. Svirko, S. V. (2006). Orhanizatsiia bukhhalterskoho obliku u biudzhetnykh ustanovakh : navch. posibn [Organization of accounting in budgetary institutions]. Kyiv: KNEU [in Ukranian].

9. Butynets F.F. Bukhhalterskyi finansovyi oblik: Pidruchnyk dlia studentiv spetsialnosti "Oblik i audyt" vyshchykh navchalnykh zakladiv [Financial accounting]. Zhytomyr, Ruta [in Ukranian].

\section{Відомості про авторів}

МЕТЕЛИЦЯ Володимир Михайлович - доктор економічних наук, старший науковий співробітник, професор кафедри обліку та оподаткування в галузях економіки, Вінницький національний аграрний університет (03127, м. Київ, вул. Дубініна Володі 2, кв. 49, e-mail: vmetelytsya@ gmail.com).

КОВАЛЬ Наталія Іванівна - кандидат економічних наук, доцент кафедри обліку та оподаткування в галузях економіки, Вінницький національний аграрний університет (21008, м. Вінниця, вул. Сонячна, 3, e-mail: Natkov@i.ua).

METELYTSYA Volodymyr - Doctor of Economics, Senior Researcher, Professor of the Accounting and Taxation in Economics Department of Vinnytsia National Agrarian University (03127, Kyiv, 2 Dubinina Volodi Str., Apt. 49, e-mail: vmetelytsya@gmail.com).

KOVAL Natalia - Ph.D, lecturer Departments of account and taxation are in industries of economy, Vinnytsia National Agrarian University (21008, Vinnytsia, Soniachna str.3, e-mail: Natkov@i.ua).

МЕТЕЛИЦА Владимир Михайлович - доктор экономических наук, старший научный сотрудник, профессор кафедры учета и налогообложения в 
отраслях экономики, Винницкий национальный аграрный университет $(03127$, г. Киев, ул. Дубинина Володи 2, кв. 49, e-mail: vmetelytsya @ gmail.com).

КОВАЛЬ Наталия Ивановна - кандидат экономических наук, доцент кафедры учета и налогообложения в отраслях экономики, Винницкий национальный аграрный университет (21008, м. Винница, ул. Солнечна, 3, еmail: Natkov@i.ua). 